\title{
Ocular copper deposition associated with monoclonal gammopathy of undetermined significance: case report
}

\author{
Depósitoocular decobre associadoa gamopatia monoclonal de significância \\ indeterminada:relatodecaso
}

Patrick F. Tzelikis ${ }^{1}$

Peter R. Laibson ${ }^{2}$

MarcoP.Ribeiro ${ }^{3}$

Christopher J.Rapuano ${ }^{4}$

Kristin M.Hammersmith ${ }^{5}$

Elisabeth J.Cohen ${ }^{6}$

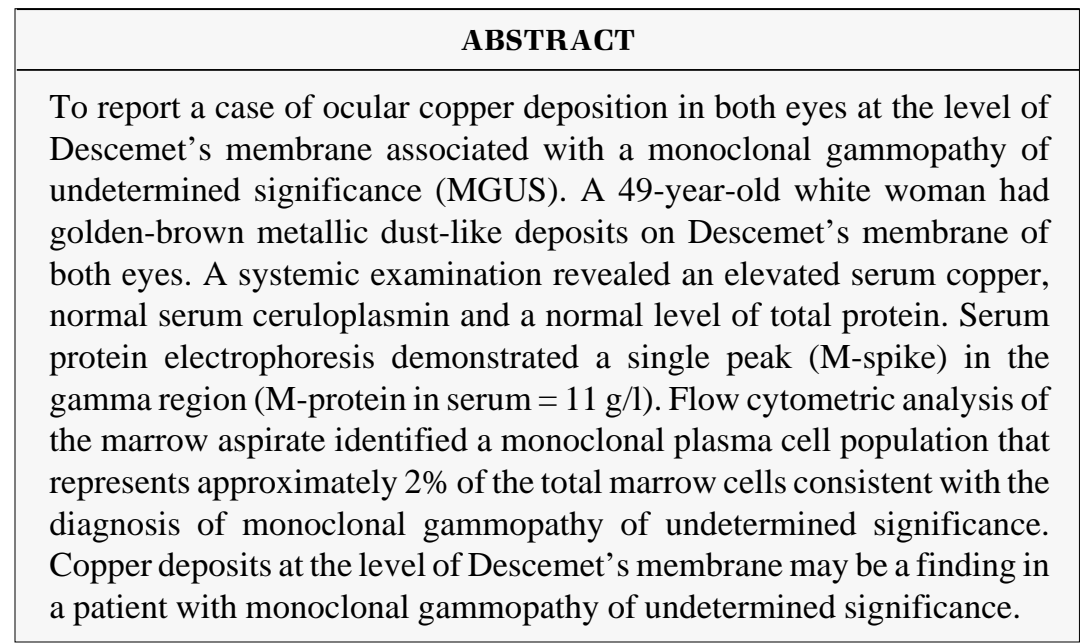

Keywords: Copper/analysis; Blood protein electrophoresis; Descemet's membrane; Gama-globulins/diagnosis; Paraproteinemias/diagnosis

\section{INTRODUCTION}

Bilateral deposition of copper on Descemet's membrane occurs in a variety of conditions associated with hypercupremia, including multiple myeloma $^{(1-3)}$, pulmonary carcinoma ${ }^{(4)}$, and also benign monoclonal gammanopathies $^{(5-6)}$. We describe the third case in the literature of deposition of copper in Descemet's membrane, which was found to be secondary to monoclonal gammopathy of undetermined significance (MGUS).

\section{CASE REPORT}

A 49-year-old white woman was referred to the Wills Eye Hospital, Philadelphia, PA, USA, when her local ophthalmologist had noticed unusual deep corneal metallic deposits in both eyes. Past medical history was negative for taking any medication. She had a history of hypertension that was not currently being medicated. There was no family history of any ocular or systemic disease and no evidence of copper exposure in the community or in the patient's family.

On examination, best corrected visual acuity (BCVA) was 20/20 in each eye. Extraocular movements and pupils were normal. There was no abnormal pigmentation of the sclera conjunctiva or mucous membrane. Biomicroscopy revealed symmetrical golden-brown metallic dust-like deposits at the level of 
Descemet's membrane in both eyes (Figure 1). Similar depositions were also noted on the anterior lens surface. The anterior chamber was free of cells and flare. The iris was normally pigmented. Dilated retinal examination revealed symmetrical normal optic discs, macula, vessels, and normal peripheral retina. Results of automated visual field examination were normal. Central ultrasound corneal pachymetry was $573 \mu \mathrm{m}$ in the right eye and $544 \mu \mathrm{m}$ in the left (Tomey SP - 2000).

Laboratory results included a hemoglobin of $13.0 \mathrm{~g} / \mathrm{dl}$, hematocrit of $38.4 \%$, mean cell volume of $85.4 \mu \mathrm{m}^{3}$, and white blood count (WBC) of $5,500 / \mathrm{mm}^{3}$. The differential WBC count included 56\% neutrophils, 38.1\% lymphocytes, and 5.9\% monocytes. Platelet level was $198,000 / \mathrm{mm}^{3}$. Total protein, albumin, globulin, bilirubin, liver function tests and electrolytes were normal. Serum copper was markedly elevated at $335 \mu \mathrm{g} / \mathrm{dl}$ (nor$\mathrm{mal}=70-155)$. Ceruloplasmin was normal. Serum protein electrophoresis demonstrated albumin fraction of $4.6 \mathrm{~g} / \mathrm{dl}$, alpha 1 fraction of $0.2 \mathrm{~g} / \mathrm{dl}$, alpha 2 fraction of $0.7 \mathrm{~g} / \mathrm{dl}$, beta fraction of $1.0 \mathrm{~g} / \mathrm{dl}$ and a single peak (M-spike) in the gamma region (Mprotein in serum $=1.1 \mathrm{~g} / \mathrm{dl}$ ) which represented monoclonal protein. Twenty-four hour urinary protein determinations averaged $0.7 \mathrm{~g} / 24 \mathrm{~h}$. Results of tests for Bence Jones proteinuria and electrophoresis of urine were consistently negative. Flow cytometric analysis of the marrow aspirate identified a monoclonal plasma cell population that represents approximately $2 \%$ of the total marrow cells. The neoplastic plasma cells expressed bright intensity IgG and lambda light chains, showing monoclonal plasmocytosis, consistent with the diagnosis of monoclonal gammopathy of undetermined significance.

Because of the risk of developing a disease such as myeloma or amyloidosis requiring therapy, the patient is being monitored with serum protein electrophoresis to observe changes in the serum M-protein level at annual intervals indefinitely for evidence of progression of the MGUS.

\section{DISCUSSION}

The clinical findings of an iridescent, multicolored, metallic sheen of copper deposition in Descemet's membrane of the cornea in our case are similar to those in two previously reported patients with hypercupremia ${ }^{(5-6)}$. Copper is an essential trace element and constitutes an integral part of several enzyme systems. Serum copper is $90-95 \%$ tightly bound to ceruloplasmin. The remaining $5-10 \%$ of serum copper is loosely associated with serum albumin, with a small fraction binding to amino acids. The binding of copper to ceruloplasmin and albumin normally prevents its penetration of the intact blood-ocular barrier ${ }^{(7-8)}$.

There are different diseases in which there is elevated serum copper, such as leukemia, lymphoma, aplastic and other anemias, myocardial infarction, congestive heart failure, rheumatoid arthritis, chronic infections, chronic liver disease, and biliary obstruction $^{(9-10)}$. In none of these conditions, however, has anterior segment copper deposition been described. Ocu-

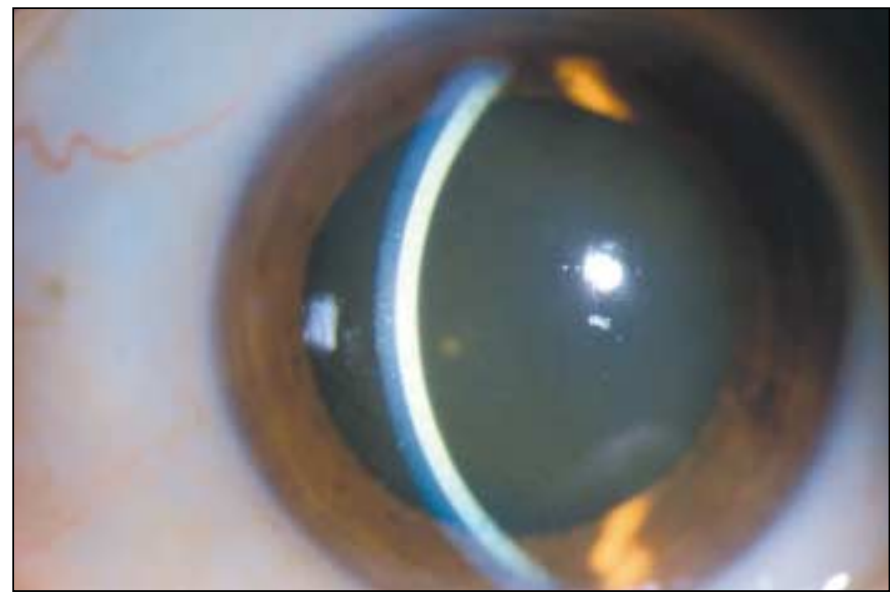

Figure 1 - Golden-brown diffuse deposits covering the entire aspect of Descemet's membrane

lar copper can also result from retained, intraocular coppercontaining foreign bodies (chalcosis) ${ }^{(11)}$.

Copper has a special affinity for the basement membrane and may accumulate in Descemet's membrane, in various diseases producing the characteristic Kayser-Fleischer ring ${ }^{(12)}$. Wilson's disease is classically associated with copper deposition in Descemet's membrane. It is an autosomal recessive disorder characterized by the generalized accumulation of copper, especially in the liver, kidneys, brain, and cornea. The biomicroscopic findings in Wilson's disease differ from those in our case. The Kayser-Fleischer ring consists of orange to greenish pigments in Descemet's membrane in the peripheral 2 to $3 \mathrm{~mm}$ of the cornea $^{(13)}$. Patients with Wilson's disease also demonstrate anterior lens capsular pigment, frequently in spokes along the Y-fissures, producing the "sunflower" cataract ${ }^{(14)}$.

In our patient, the ocular manifestations of hypercupremia were the first sign of monoclonal gammopathy of undetermined significance. The term MGUS denotes the presence of a monoclonal protein in persons without evidence of multiple myeloma, macroglobulinemia, amyloidosis, or other related plasma cell or lymphoproliferative disorders. Similar terms have been used including benign, idiopathic, asymptomatic, non-myelomatous, discrete, and others ${ }^{(15-17)}$. The term benign monoclonal gammopathy is misleading because at diagnosis it is not known whether the process will remain stable and asymptomatic or will develop into symptomatic multiple myeloma, macroglobulinemia, amyloidosis or a related lymphoproliferative cell disorder. The major risk factor for progression to multiple myeloma is the level of M-protein ${ }^{(15)}$. In a study done in 1984 , over a period of 10 years, $10 \%$ of these patients developed multiple myeloma or primary amyloidosis ${ }^{(16)}$. In the Mayo Clinic series, 2004, the median survival rate of study patients with MGUS (241 patients) was only slightly shorter than that of a comparable US population ${ }^{(18)}$. The risk of progression of MGUS to multiple myeloma or a related disorder, was shown to be about $1 \%$ per year, is indefinite and persists 
even after more than 30 years of follow-up, with no reliable predictors of malignant evolution.

MGUS occurs in $1 \%$ of persons older than 50 years and $3 \%$ of persons over 70 years ${ }^{(17)}$. The criteria recommended by the International Myeloma Working Group for the diagnosis of MGUS is a M-protein in serum $<3.0 \mathrm{~g} / \mathrm{dl}$, bone marrow clonal plasma cells $<10 \%$ and low level of plasma cell infiltration in a trephine biopsy (if done), no evidence of other B-cell proliferation disorders, and no related organ or tissue impairment ${ }^{(15-17)}$. In our patient, the MG was of the undetermined variety. The serum M-protein level was less than $3.0 \mathrm{~g} / \mathrm{dl}$, plasma cell content of $2 \%$ in the bone marrow and no evidence of B-cell proliferation or organ impairment.

The only certain approach in patients with MGUS is to monitor changes in the serum M-protein level. If a patient has no features of myeloma or amyloidosis and the serum Mprotein level is less than $1.5 \mathrm{~g} / \mathrm{dl}$, serum protein electrophoresis should be repeated annually. If the patient has an $\mathrm{M}$ protein level of 1.5 to $2.0 \mathrm{~g} / \mathrm{dl}$, the $\operatorname{IgG}, \operatorname{IgA}$, and IgM levels should be measured and a 24-hour urine specimen should be collected for electrophoresis and immunofixation as a baseline. Serum protein electrophoresis should be repeated 6 months later and, if stable, should be repeated annually or sooner if symptoms develop. If the $\operatorname{IgG}$ or $\operatorname{IgA} \mathrm{M}$ protein level is higher than $2.0 \mathrm{~g} / \mathrm{dl}$, a metastatic bone survey, including views of the humeri and femurs, should be performed in addition to a bone marrow aspirate and biopsy. If the patient has an IgM Mprotein level higher than $2.0 \mathrm{~g} / \mathrm{dl}$, aspiration and biopsy of the bone marrow and computed tomography of the abdomen may be useful to recognize macroglobulinemia or a related lymphoproliferative disorder ${ }^{(18)}$.

In summary, we report a rare case of ocular copper deposition associated with monoclonal gammopathy of undetermined significance and hypercupremia. The presence of metallic-appearing pigmented deposits in the cornea or lens capsule should alert the ophthalmologist to the possibility of monoclonal gammopathies including monoclonal gammopathy of undetermined significance, multiple myeloma, Waldenström's macroglobulinemia, amyloidosis, chronic infections, renal disease, malignant lymphoma, and other neoplasms. Patients with MGUS need to be evaluated systemically for this disorder indefinitely for evidence of progression.

\section{RESUMO}

Relatar um caso de depósito corneano de cobre em ambos os olhos a nível da membrana de Descemet associado a gamopatia monoclonal de significância indeterminada (GMSI). Paciente feminina, 49 anos, leucodérmica, apresentando depósito corneano de aspecto marrom-ouro a nível da membrana de Descemet em ambos os olhos. Exame sistêmico revelou cobre sérico elevado, ceruloplasmina sérica normal, e proteína total normal. Eletroforese de proteínas séricas demonstrou um pico único na região gama (proteína $\mathrm{M}=11 \mathrm{~g} / \mathrm{l}$ ). Análise citométrica de aspirado medular evidenciou uma população de células plasmáticas monoclonais de aproximadamente $2 \%$ do total de células medulares consistente com o diagnóstico de gamopatia monoclonal de significância indeterminada. Depósitos de cobre a nível da membrana de Descemet podem ser encontrados em pacientes com gamopatia monoclonal de significância indeterminada.

Descritores: Cobre/análises; Eletroforese de proteínas sangüíneas; Membrana de Descemet; Gamaglobulina/diagnóstico; Paraproteinemias/diagnóstico

\section{REFERENCES}

1. Goodman SI, Rodgerson DO, Kauffman J. Hypercupremia in a patient with multiple myeloma. J Lab Clin Med. 1967;70(1):57-62.

2. Lewis RA, Falls HF, Troyer DO. Ocular manifestations of hypercupremia associated with multiple myeloma. Arch Ophthalmol. 1975;93(10):1050-3.

3. Hawkins AS, Stein RM, Gaines BI, Deutsch TA. Ocular deposition of copper associated with multiple myeloma. Am J Ophthalmol. 2001;131(2):257-9.

4. Martin NF, Kincaid MC, Stark WJ, Petty BG, Surer JL, Hirst LW, et al Ocular copper deposition associated with pulmonary carcinoma, IgG monoclonal gammopathy and hypercupremia. A clinicopathologic correlation. Ophthalmology. 1983;90(1):110-6.

5. Probst LE, Hoffman E, Cherian MG, Yang J, Feagan B, Adams P, et al. Ocular copper deposition associated with benign monoclonal gammopathy and hypercupremia. Cornea. 1996;15(1):94-8.

6. Lewis RA, Hultquist DE, Baker BL, Falls HF, Gershowitz H, Penner JA. Hypercupremia associated with a monoclonal immunoglobulin. J Lab Clin Med. 1976;88(3):376-88

7. Evans GW. Copper homeostasis in the mammalian system. Physiol Rev. 1973;53(3):535-70.

8. Cook CS, Grubb B. Experimental hypercupremia does not result in increases in copper in the lens, iris, or ocular fluids. Curr Eye Res. 1986;5(2):171-3.

9. Brown DH, Buchanan WW, El-Ghobarey AF, Smith WE, Teape J. Serum copper and its relationship to clinical symptoms in rheumatoid arthritis. Ann Rheum Dis. 1979;38(2):174-6.

10. McCall JT, Goldstein NP, Smith LH. Implications of trace metals in human diseases. Fed Proc. 1971;30(3):1011-5.

11. Rao NA, Tso MO, Rosenthal AR. Chalcosis in the human eye. A clinicopathologic study. Arch Ophthalmol. 1976;94(8):1379-84.

12. Tauber J, Steinert RF. Pseudo-Kayser-Fleischer ring of the cornea associated with non-Wilsonian liver disease: a case report and literature review. Cornea. 1993;12(1):74-7.

13. Uzman LL, Jakus MA. The Kayser-Fleischer ring: a histochemical and electron microscope study. Neurology. 1957;7(5):341-55.

14. Tso MOM, Fine BS, Thorpe HE. Kayser-Fleischer ring and associated cataract in Wilson's disease. Am J Ophthalmol. 1975;79(3):479-88.

15. International Myeloma Working Group. Criteria for the classification of monoclonal gammopathies multiple myeloma and related disorders: a report of the International Myeloma Working Group. Br J Haematol. 2003;121(5):749-57.

16. Kyle RA. "Benign" monoclonal gammopathies. A misnomer? JAMA. 1984; 251(14):1849-54.

17. Axelsson U. A 20-year follow-up study of 64 subjects with M-components. Acta Med Scand. 1986;219(5):519-22.

18. Kyle RA, Therneau T, Rajkumar SV, Larson DR, Plevak MF, Melton LJ. Long-term follow-up of 241 patients with monoclonal gammopathy of undetermined significance: the original Mayo Clinic series 25 years later. Mayo Clinic Proc. 2004;79(7):859-66. Comment in: Mayo Clin Proc. 2004;79(7):855-6. 